\title{
Wind Structure of the Boundary Layer Over the Tropical Ocean
}

\author{
By M. Mizuma and S. Iwamoto \\ Research Reactor Institute, Kyoto University, Kumatori, Osaka 590-04, Japan
}

(Manuscript received 12 April 1982, in revised form 21 October 1982)

\begin{abstract}
Ship-based measurements of wind profiles in the boundary layer were carried out successfully in the tropical western Pacific, as a part of the observational program of the MONEX in Japan. A wind-finding procedure by use of pilot-balloon observation on board a ship is developed for the present study. Observed wind field in the boundary layer shows the characteristics of the mixed layer, that is, the layer of uniform wind speed and direction in the vertical. The depth of the layer almost corresponds with that of the mixed layer determined from the thermodynamical structure of the boundary layer. The results seem to be in contrast with the general feature in the undisturbed trade winds where there appears appreciable vertical shear of wind speed in the thermodynamically determined mixed layer. A few estimations of cross-isobar angle and ratio of actual to geostrophic wind speed of the boundary layer wind are made, though roughly, in good agreement with climatological value in lower latitudes. An evidence is obtained that the depth of "a density current" by downdraft in front of the squall cell is about two hundred meters above the sea surface.
\end{abstract}

\section{Introduction}

The wind structure of the planetary boundary layer (PBL) has studied from observational and theoretical point of view in greater detail in the last few decades. The studies, however, are mostly conducted in the middle latitudes. As regards the PBL winds in lower latitudes, we are very familiar with the results about those in the trade wind regime in the northern hemisphere. After the World War II, several investigators have done observational studies on the PBL winds in the northeasterly trade winds in the Atlantic (e.g. Charnock et al., 1956). Recently, GARP Atlantic Tropical Experiment provides useful data on the dynamical and thermodynamical structure of the boundary layer over the tropical Atlantic (e.g. Düing, 1980). Observing areas of these studies, however, are mainly north of about $10^{\circ} \mathrm{N}$. Then, theoretical explanation of the results obtained (Holland and Rasmusson, 1973) was based on the framework including the Coriolis parameter like that in the middle latitudes (Sheppard et al., 1952). Few studies have been published regarding the boundary layer winds in the vicinity of the Equator. An obsegr- vational study was made at Christmas Island situated at the latitudes of $2^{\circ} \mathrm{N}$ by Estoque (1971). He made double-theodolite pilot-balloon cbservations during a period of about a month and obtained a lot of wind profiles in the lowest 2000 meters layer of the atmosphere. He succeeded, to some extent, in resolving his results by use of geostrophic and thermal wind relations. His findings, however, are to be considered inconclusive because an observational study by Romanov and Romanova (1976) showed that the observed wind direction, though only that of surface wind, was far from the geostrophic wind direction expected from the atmospheric pressure field observed around the Equator. Augstein (1972) also reported observational results about the boundary layer winds at the Equator in the Atlantic. There are a few investigators who solved theoretically the vertical structure of the boundary layer winds in low latitudes including the Equator (Pushistov, 1970: Mahrt. 1972: Kriverevich and Laykhtman, 1975), but- they did not discuss so much about verification of their solutions against existing observations. In summary, there exist few definite conclusions, both theoretical and observational, about the bound- 
ary layer winds around the Equator.

The R.V. Hakuho Maru of the University of Tokyo made a cruise to the tropical western Pacific in May, 1979, to participate in the summer MONEX Field Experiment and TWOS in Special Observing Period II of FGGE. She stayed at a fixed station at the intersection of $2^{\circ} \mathrm{N}$ and $140^{\circ} \mathrm{E}$ for two weeks during the cruise; pilot-balloon observations of the boundary layer winds were carried out as a part of the observational program of the MONEX in Japan. The observed results are analyzed together with those of thermodynamical structure of the boundary layer by use of the lower troposphere radiosonde (LTS) and other related observations for the purpose of representing the vertical structure of the boundary layer winds in the vicinity of the Equator.

\section{Observations}

Pilot-balloon observation on board a ship meets difficulties other than those in the observation on land; the ship deck which makes the platform for the theodolite is always swaying with the waves. A new simple method has been developed, which consists of a new type of digital theodolite fixed to the ship body, ship-motion- sensors and data processing technique for correction of ship sway. It was first practised in the present observation. Method of observation and data reduction are described briefly elsewhere by the present authors (Mizuma and Iwamoto, 1980). Computational procedure is shown here.

We consider two coordinate systems, both of which have the same origin at the ship-fixed theodolite: (1) $(X, Y, Z)$ coordinate system in which the $X$ axis points toward the east, the $Y$ axis toward the north and the $Z$ axis toward the local zenith, (2) $(\xi, \eta, \zeta)$ coordinate system in which the $\xi$ axis points toward the bow of the ship, the $\eta$ axis toward the port beam and the $\zeta$ axis upward along the normal to the deck. Suppose that at any instant when a reading of the theodolite angles is done, the ship pitches $\theta$ by the bow-down angle, rolls $\lambda$ by the portdown angle and the ship azimuth is $\psi$ from the north. Further, direction cosine of line segment from the theodolite to the pilot-balloon in ( $X$, $Y, Z)$ coordinate frame is denoted by $\left(A_{X}, A_{Y}\right.$, $\left.A_{Z}\right)$ and that in the $(\xi, \eta, \zeta)$ coordinate frame $\left(A_{\xi}, A_{\eta}, A_{\zeta}\right)$ which is easily determined from the theodolite angles observed. The following relation holds between them:

$$
\left(\begin{array}{l}
A_{\mathrm{X}} \\
A_{\mathrm{Y}} \\
A_{\mathrm{Z}}
\end{array}\right)=\left(\begin{array}{ccc}
\cos \theta \sin \phi & -\cos \lambda \cos \phi-\sin \theta \sin \lambda \sin \phi & -\sin \lambda \cos \phi+\sin \theta \cos \lambda \sin \phi \\
\cos \theta \cos \phi & \cos \lambda \sin \phi-\sin \theta \sin \lambda \cos \phi & \sin \lambda \sin \psi+\sin \theta \cos \lambda \cos \phi \\
-\sin \theta & -\cos \theta \sin \lambda & \cos \theta \cos \lambda
\end{array}\right)\left(\begin{array}{l}
A_{\xi} \\
A_{\eta} \\
A_{\xi}
\end{array}\right)
$$

The $3 \times 3$ matrix in this relation is called the coordinate transformation matrix which has already been shown in some meteorological studies using moving platform (e.g. Axford, 1968). Coordinates $(x, y, z)$ of the balloon are given in the followings;

$$
x=\frac{A \mathrm{x}}{A z} \cdot H, y=\frac{A \mathrm{Y}}{A z} \cdot H, z=H,
$$

provided that the height $H$ of the balloon at that instant is given from the time after release of the balloon as is the case with the single-theodolite observation. Nominal ascent rate is 200 meters a minute for the present observation. When the ship is anchoring, components of the velocity of wind aloft are immediately calculated from the above coordinates. In case of ship's cruising, it is necessary only to add to those components the corresponding components of the ship velocity to obtain the components of the true wind velocity. In this connection, similar procedure has been employed for the rawin observations on board of the Keifu Maru of
Japan Meteorological Agency since 1970.

In the present pilot-balloon observation, the theodolite angles were recorded whenever a balloon under tracking was caught in sight correctly during the period of tracking, in contrast with in the usual one. Then, there are data-rich and data-sparse domains in a time series of calculated coordinates of the balloon for each ascent, in which erroneous, high-frequency variations take place owing to observational difficulties on the swaying ship. For the present analysis, some procedure is to be introduced for high-frequency variations leading to variable wind profile to be suppressed and for coordinates of the balloon to be interpolated at equal intervals during the period of tracking. Objective analysis based on the calculus of variations initiated by Sasaki (1958) and recently in wider use (Ninomiya and Akiyama, 1978, 1979) is suitable for the present purpose.

Here, horizontal coordinates $(x, y)$ of the balloon are separately subject to the variational 
analysis using observational and low-pass filtering constraints developed by Wagner (1971). The procedure is described briefly in this paper.

An appropriate quantity to be minimized is

$$
J=\sum_{\Omega}\left\{\tilde{\alpha}(\varphi-\tilde{\varphi})^{2}+\alpha(\nabla \varphi)^{2}+\beta\left(\nabla^{2} \varphi\right)^{2}\right\}
$$

where $\tilde{\varphi}$ is the observed value of any one of the $(x, y)$ coordinates, $\varphi$ the analyzed one and $\tilde{\alpha}, \alpha$, $\beta$ are weight factors for observational constraint, first- and second-filter, respectively. Summation is taken for the whole time domain for analysis. Minimization is attained when $\varphi$ is the solution of the Euler-Lagrange Equation

$$
\tilde{\alpha}(\varphi-\tilde{\varphi})-\alpha \nabla^{2} \varphi+\beta \nabla^{4} \varphi=0
$$

where

$$
\begin{aligned}
& \nabla^{2} \varphi=\frac{\varphi_{i+1}-2 \varphi_{i}+\varphi_{i_{-1}}}{(\Delta t)^{2}} \\
& \nabla^{4} \varphi=\frac{\varphi_{i_{+}-2}-4 \varphi_{i+1}+6 \varphi_{i}-4 \varphi_{i-1}+\varphi_{i-2}}{(\Delta t)^{4}}
\end{aligned}
$$

For the present analysis, the time step $\Delta t$ is taken as 3 seconds. The ratio $\beta / \tilde{\alpha}$ is taken to be 10 for fluctuations having periods shorter than 20 seconds to be effectively smoothed out in the analysis using $\Delta t=3 \mathrm{sec} ; \alpha$ is zero, that is, the first-filter is not used. An example of the analyzed results is shown in Fig. 1. Effects of

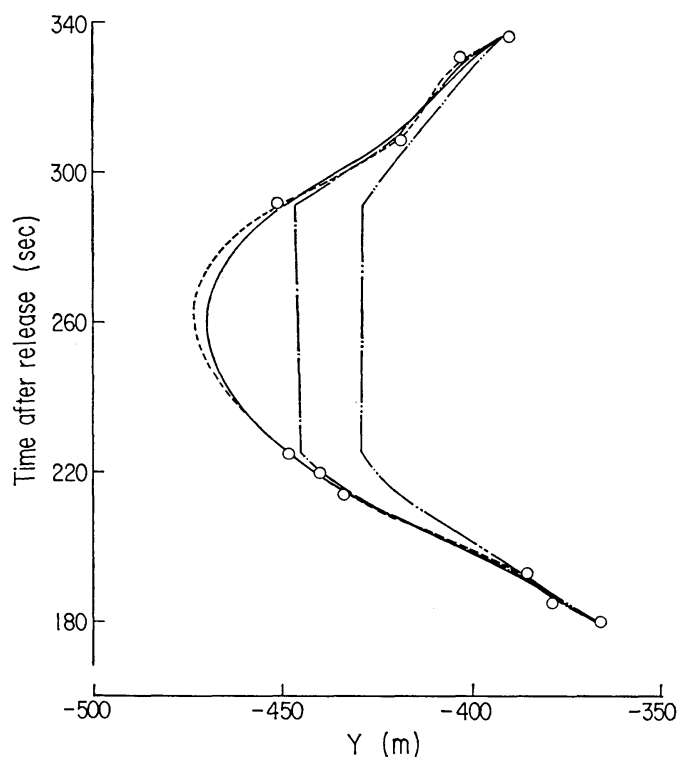

Fig. 1 Effects of variational filters on smoothing.

O: observed value.

-: analyzed result with $\alpha=0, \beta / \tilde{\alpha}=10$.

-..-: with $\alpha=0, \beta / \tilde{\alpha}=1$.

-.-.-: with $\alpha / \tilde{\alpha}=1, \beta=0$.

-..-.-: with $\alpha / \tilde{\alpha}=10, \beta=0$. various variational filters on smoothing are clearly seen and the present choice of weight factors is pertinent. For the later analysis, horizontal coordinates of the balloon are interpolated from the analyzed results at an interval of 100 meters height and components of the wind velocity are calculated from those interpolated coordinates.

\section{Observed results and discussion}

The fixed station of the MONEX cruise of the R.V. Hakuho Maru is at an intersection of $2^{\circ} \mathrm{N}$ and $140^{\circ} \mathrm{E}$, where the surface wind is rather variable in the equatorial Pacific as is suggested by Riehl (1979). In fact, during the observation at the station, the observing area might be under influence of three different synoptic weather conditions: (1) the intertropical convergence zone from 9th to 14th, May, (2) the equatorial doldrums from 15 th to 17 th, May, (3) presumably the northeast trade winds from 18th to $21 \mathrm{st}$, May. Such variability of the synoptic weather conditions makes analysis of the observed results difficult to draw some definite conclusions from rather small number of observations. For the comparative purpose, pilot-balloon observations made at some small islands near the Equator are analyzed, whose observing period is from 15 th, April to 31st, July, 1956 corresponding to the period of an atomic test by the United States of America (Operation REDWING). Observations in May at two stations, that is, Tarawa and Kapingamarangi, situated at about $1^{\circ} \mathrm{N}$ are adopted presently on account of their similarity of the latitude and observing period to the present observation. The boundary layer winds below about 1500 meters height at Tarawa located at $173^{\circ} \mathrm{E}$, however, are highly predominated by the easterly wind in contrast to the present observation; there appear only a few days of wind with other direction. At Kapingamarangi situated at $155^{\circ} \mathrm{E}$, constancy of the easterly wind is slightly reduced; there are several days of calm or westerly wind in May.

Published results of observations of the boundary layer winds in the tropical regions are characterized by the relatively small temporal change of the large-scale wind fields; usually the longterm averaged wind profile can be made, for sampling errors to be reduced, of individual profiles observed at intervals of several hours or more. In contrast, the present observations show considerable temporal change of the large-scale wind field except for those in 20th and 21st, May 
during which the fixed station is presumably under influence of the northeast trade winds. Then, such long-term averaging as in the previous observations is not suitable for the present. Instead, successive ascents of several balloons were done within a period of about an hour which is said to be suitable for the sampling duration of the PBL phenomena and a representative wind profile is made by averaging individual profiles observed.

As regards the vertical structure of the tropical

Table 1 Depth of mixed layer determined from LTS observation.

\begin{tabular}{cccc}
\hline $\begin{array}{l}\text { LTS- } \\
\text { Run }\end{array}$ & Date & Time (JST) & $\begin{array}{c}\text { Depth of } \\
\text { mixed layer } \\
(\mathrm{m})\end{array}$ \\
\hline 11 & May 10 & $08: 21-08: 35$ & 300 \\
12 & 10 & $16: 27-16: 40$ & 400 \\
13 & 11 & $00: 38-00: 50$ & 700 \\
26 & 14 & $05: 00-05: 13$ & 300 \\
28 & 14 & $13: 04-13: 12$ & 400 \\
29 & 14 & $17: 38-17: 50$ & 400 \\
30 & 14 & $21: 00-21: 18$ & 400 \\
35 & 16 & $12: 17-12: 29$ & 300 \\
37 & 16 & $20: 19-20: 30$ & 700 \\
41 & 18 & $00: 21-00: 33$ & 600 \\
42 & 18 & $04: 16-04: 26$ & 600 \\
43 & 18 & $08: 22-08: 32$ & 700 \\
44 & 18 & $12: 25-12: 36$ & 800 \\
45 & 18 & $16: 09-16: 23$ & 800 \\
46 & 18 & $20: 17-20: 27$ & 200 \\
50 & 20 & $08: 23-08: 40$ & 900 \\
51 & 20 & $16: 30-16: 42$ & 600 \\
53 & 21 & $08: 14-08: 26$ & 700 \\
\hline
\end{tabular}

boundary layer, that of the undisturbed trade winds is made clear to a considerable extent on the observational basis (Sheppard and Omar, 1952; Charnock et al., 1956; Estoque, 1971; Augstein, 1972; Holland and Rasmusson, 1973; Augstein et al., 1974; Brümmer, 1976; Aspliden et al., 1978; Shinha and Khade, 1980). Existence of maximum in vertical profile of wind speed is pointed out; the height of the maximum wind speed is usually found in the mixed layer. Vertical shear of wind speed below the height of the maximum is usually less than $3 \times 10^{-3} \mathrm{sec}^{-1}$, suggesting an excellent mixing of momentum throughout the mixed layer (Augstein et al., 1974). Larger wind shear is found by some investigators (Sheppard and Omar, 1952; Aspliden et al., 1978; Sinha and Khade, 1980), but in their studies, the existence of the mixed layer is not referred to. In contrast, tropical boundary layer wind measurements in situations such as those near the intertropical convergence zone, i.e. other than the undisturbed trade wind weather, show that the wind speed does not change significantly with height in the presence of the mixed layer (Kraus and Hudson, 1974; Barnes et al., 1980; Nicholls and LeMone, 1980; Fitzjarrald and Garstang, 1981). Through the observations on the R.V. Hakuho Maru, Monji et al. (1981) pointed out the existence of the mixed layer from the examination of vertical profiles of virtual potential temperature obtained from the LTS observations. They showed that the mixed layer exists usually below several hundred meters height and is deeper in fine weather than in

Table 2 Pilot-balloon observation in MONEX in Japan

\begin{tabular}{|c|c|c|c|c|c|c|}
\hline \multirow{2}{*}{ Run } & \multirow{2}{*}{\multicolumn{2}{|c|}{ Date }} & \multicolumn{2}{|c|}{$\begin{array}{l}\text { Balloon release } \\
\text { time (JST) }\end{array}$} & \multirow{2}{*}{$\begin{array}{l}\text { Number of } \\
\text { balloons } \\
\text { released }\end{array}$} & \multirow{2}{*}{ Clouds } \\
\hline & & & first & last & & \\
\hline 2 & May 1 & 10 & $13: 54$ & $14: 54$ & 7 & $10^{-}$, As $\mathrm{Cu} \mathrm{Ac}$ \\
\hline 3 & & 10 & $20: 27$ & $21: 25$ & 7 & $10, \mathrm{As} \mathrm{Cu}$ \\
\hline 6 & & 14 & 13:56 & $14: 57$ & 7 & $10, \mathrm{Ns}-\mathrm{As} \mathrm{Cu}$ \\
\hline 7 & & 14 & 18:01 & $18: 48$ & 5 & $10-2$, Sc As \\
\hline 9 & & 16 & $13: 12$ & $14: 18$ & 7 & $4-6, \mathrm{Cu} \mathrm{Ci} \mathrm{Ac}$ \\
\hline 10 & & 16 & $20: 47$ & $21: 48$ & 7 & $0^{+}-2, \mathrm{Ac}$ \\
\hline 11 & & 18 & $00: 48$ & $01: 42$ & 7 & $0^{+}-2, \mathrm{Ac} \mathrm{Cu}$ \\
\hline 12 & & 18 & 04:38 & $05: 27$ & 7 & $1-5, \mathrm{Cu}$ \\
\hline 13 & & 18 & $08: 45$ & $09: 36$ & 7 & $1-3, \mathrm{Ac} \mathrm{Cu} \mathrm{Ci}$ \\
\hline 14 & & 18 & $12: 53$ & $13: 54$ & 6 & $1-4, \mathrm{Cu} \mathrm{Ac}$ \\
\hline 16 & & 18 & $20: 43$ & $21: 42$ & 7 & $4-10$, Sc As \\
\hline 17 & & 20 & $09: 28$ & $10: 20$ & 7 & $0^{+}, \mathrm{Cu} \mathrm{Ci} \mathrm{Cc}$ \\
\hline 18 & & 20 & $14: 05$ & $14: 55$ & 7 & $0^{+}-3, \mathrm{Cu}$ \\
\hline 19 & & 21 & 09:12 & $10: 05$ & 7 & $0^{+}-1, \mathrm{Cu} \mathrm{Ci}$ \\
\hline 20 & & 21 & $12: 58$ & $13: 50$ & 7 & $1-2, \mathrm{Cu}$ Cs $\mathrm{Ci}$ \\
\hline
\end{tabular}


cloudy or rainy weather. Mixed layer depth obtained from the LTS observations (Yoshikado and Monji, 1980 is shown in Table 1. It is interesting to seek what feature is found in the vertical structure of the boundary layer winds. There are fifteen wind profiles, as are shown in Table 2, appropriate for such investigations, each of which is made by averaging usually seven profiles obtained from successive ascents of the balloons during about an hour. Vertical profiles of wind speed and direction are shown in Fig. 2; arrows beside the profiles show the depth of the mixed layer estimated from those in Table 1.

There hardly appear profiles with maximum speed in the mixed layer; peak in wind speed, if appearing, exists in the overlying layer. Wind shear in the mixed layer is considerably small less than $2 \times 10^{-3} \mathrm{sec}^{-1}$. Moreover, there are a few profiles in which the speed at the top of the mixed layer is weaker than that at the lowest observing level. Numerical value of wind shear obtained is rather smaller than those reported previously in the undisturbed trade winds. Turning of wind direction in the mixed layer is, with few exceptions, smaller than 10 degrees, in contrast with greater change with height in the overlying layer, as is clearly seen in Fig. 2. Wind velocity shown in Fig. 2 is divided into two components, that is, one along a mean wind direction in the mixed layer and the other perpendicular to this direction. These two components are normalized by a mean wind speed in the mixed

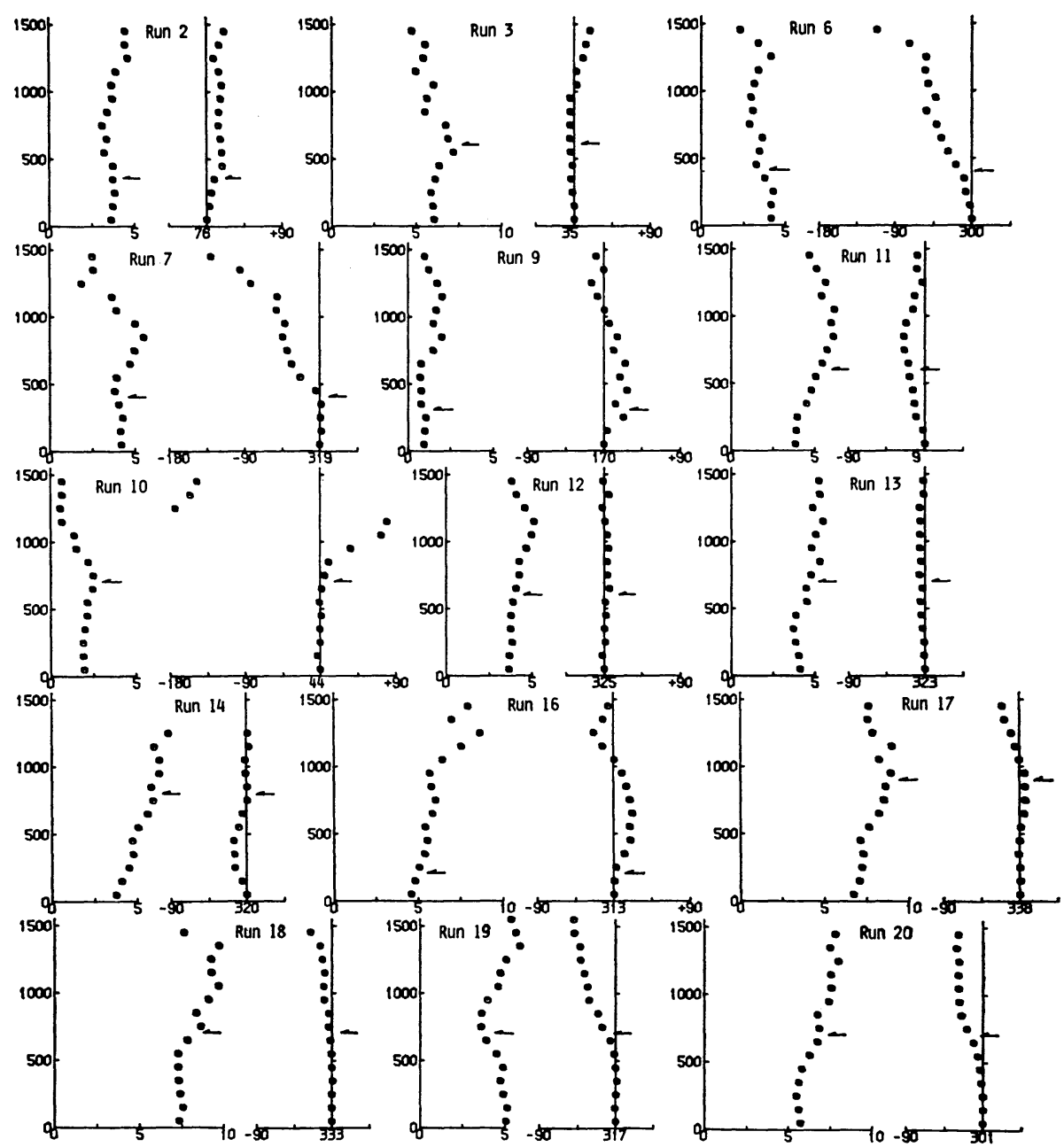

Fig. 2 Mean wind profiles for each run. Left: wind speed $(\mathrm{m} / \mathrm{s})$. Right: wind direction (deg). Height is shown in meters. 

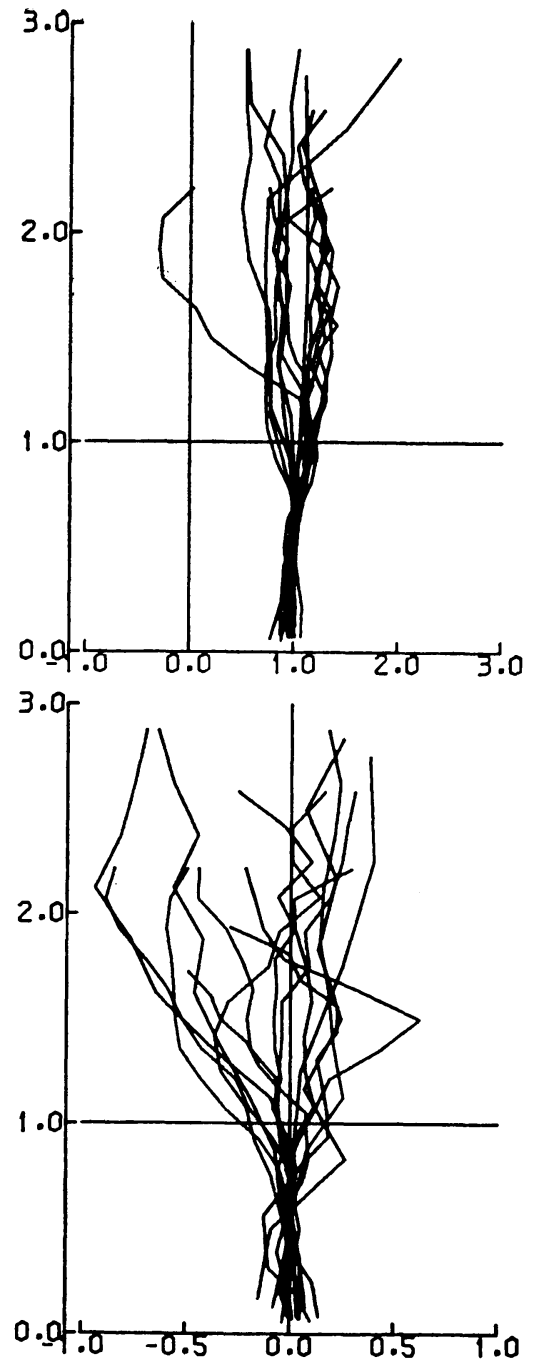

Fig. 3 Normalized wind profiles. Abscissa: normalized speed, ordinate: normalized height. Upper: velocity component along a mean wind direction in the mixed layer, lower: velocity component perpendicular to that direction. For details see text.

layer and plotted against a corresponding height normalized by the depth of the mixed layer. Fig. 3 shows such normalized wind profiles all together. Uniformity of winds in the mixed layer is clearly shown. It is concluded that the wind profiles obtained is considerably of mixed layer type which shows uniform wind speed and direction in the vertical, in the mixed layer determined from thermodynamical structure of the boundary layer. It may also be said that the depth itself of the mixed layer from viewpoint of wind structure almost corresponds with that from thermodynamical structure of the boundary layer.

Different situation is found from the analysis of the observation at Tarawa and Kapingamarangi near the Equator in May, 1956. Pilot-balloon observations were carried out usually four times a day. Then, a day when wind direction is significantly steady is chosen and four profiles at that day are averaged for sampling errors to be reduced. An example of daily mean profiles is shown in Fig. 4. Significant vertical shear of wind speed exists in the lowest part of the atmosphere below about 1000 meters height; the layer of uniform wind speed does not appear in contrast with the present observations. Furthermore, wind profiles are averaged over 23 days of highly predominant easterly wind in May, 1956; constancy of wind at about 900 meters height is 0.97 and 0.92 for Tarawa and Kapingamangi, respectively. The profiles obtained are shown in Fig. 5. Wind shear in the lowest layer is still significant in such long-term mean profiles. Sounding of temperature and humidity aloft are not sufficient for examination of the mixed layer. Influence of the island body is unlikely, judging from the description of the observing site. Similar wind profile is also found in the observations at the Equator (Augstein, 1972). As is mentioned above, the present fixed station is at the western end of the northeast trade wind regime and frequently under influence of the intertropical convergence zone. It may, therefore, be seldom that the typical undisturbed trade wind situation appears over the observing area, which may correspond with rare occurrence of the wind profile with maximum in the mixed layer. While, the Tarawa and Kapingamarangi where there appears the typical undisturbed trade wind situation, observed wind profile with maximum in the lowest 1000 meters above the earth's surface is certainly the general feature of the trade wind mixed layer where there is vertical shear, whether larger or smaller, of the horizontal wind.

Next, the observed relation between wind field and atmospheric pressure field is briefly discussed. Data of atmospheric pressure available at hand for the present observation are only measurements on the R.V. Hakuho Maru, Keifu Maru of Japan Meteorological Agency located at the intersection of $2^{\circ} \mathrm{N}$ and $130^{\circ} \mathrm{E}$, Koror at $7.6^{\circ} \mathrm{N}$ and $134.8^{\circ} \mathrm{E}$ and $\mathrm{Yap}$ at $9.8^{\circ} \mathrm{N}$ and $138.1^{\circ} \mathrm{E}$ and only twice a day. Distance be- 

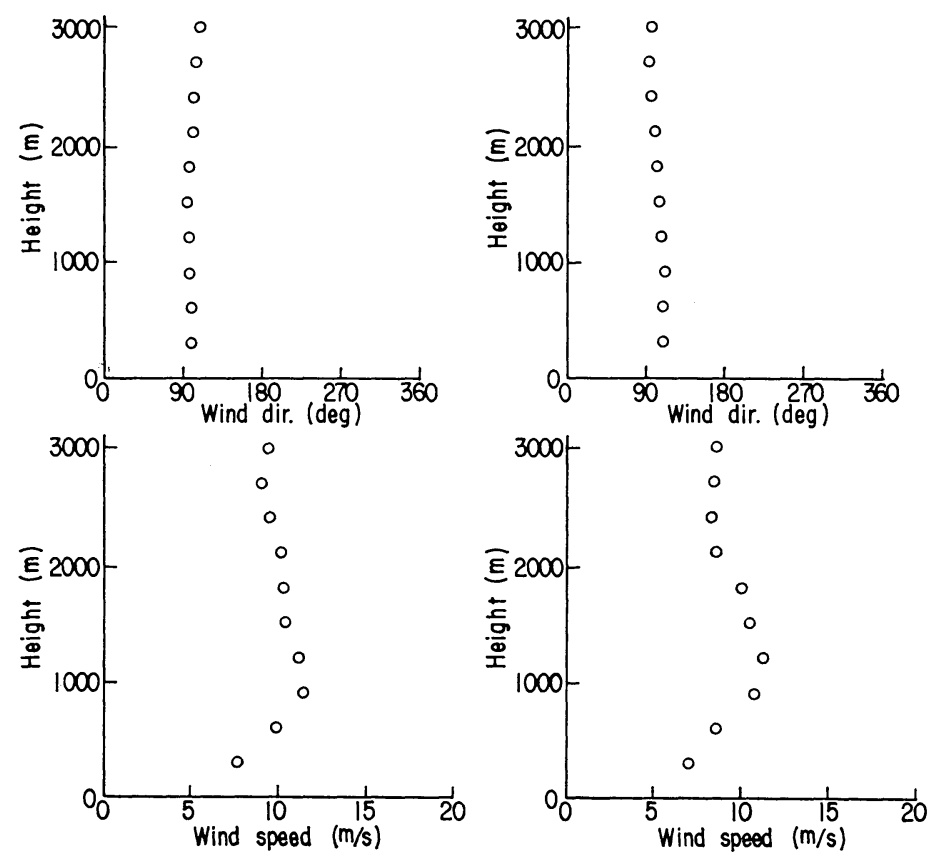

Fig. 4 Daily mean wind profile in 13th, May, 1956. Left: Tarawa. Right: Kapingamarangi.
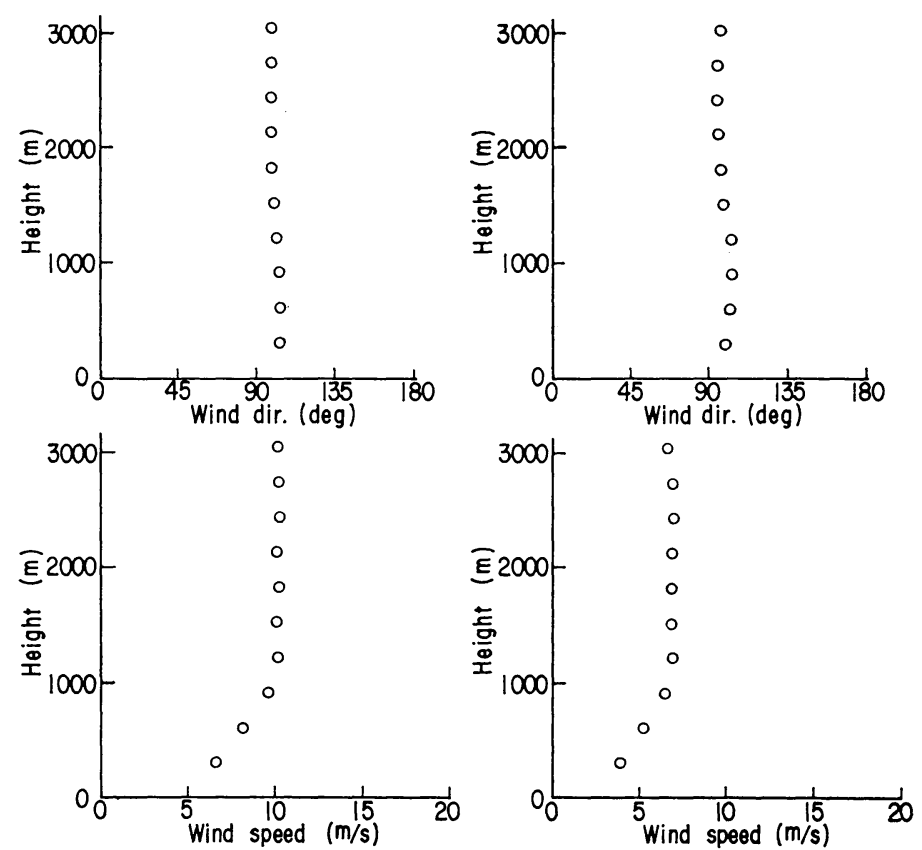

Fig. 5 Long-term mean wind profile in May, 1956. Left: Tarawa. Right: Kapingamarangi. 
tween these stations is several hundred kilometers and seems too distant for evaluation of local pressure gradient. Then, only data obtained on 20th and 21st, May are discussed, when evaluated pressure gradients are rather constant in their direction and wind field is considerably stationary. Pressure gradients are first calculated by use of triangles composed of the following three combinations of the stations, that is, HakuhoKeifu-Koror, Hakuho-Keifu-Yap and HakuhoKoror-Yap. Then, these three gradients are vectorially averaged for the appropriate pressure gradient. The results are shown in Table 3. Cross-isobar angle at around 100 meters level amounts to about 50 degrees and ratio of actual to geostrophic wind speed is about 0.3. These values are in good agreement with climatological values obtained by Gordon (1952) and discussed by Clarke and Hess (1975). For comparative purpose, those at around 1500 meters level are also shown in the Table. Cross-isobar angles obtained are still larger, almost at right-angles. These findings, however, are based on the observations during only two days and are merely taken as a research material for further comprehensive studies. As is evident from the Table, counterclockwise turning of wind direction with height takes place in contrast with the customary Ekman spiral concept. In this context, semi-diurnal variations of atmospheric pressure and accompanying wind (e.g. Hastenrath, 1972; Prümm, 1976) are not taken into consideration.

An interesting feature is obtained from successive pilot-balloon observations just before the occurrence of squall in the evening on 18th,
May; the rainfall amounts to $10 \mathrm{~mm}$ in a period of two hours. Before the squall, only two ascents were able to be completed. The results obtained are shown in Fig. 6 in which are shown

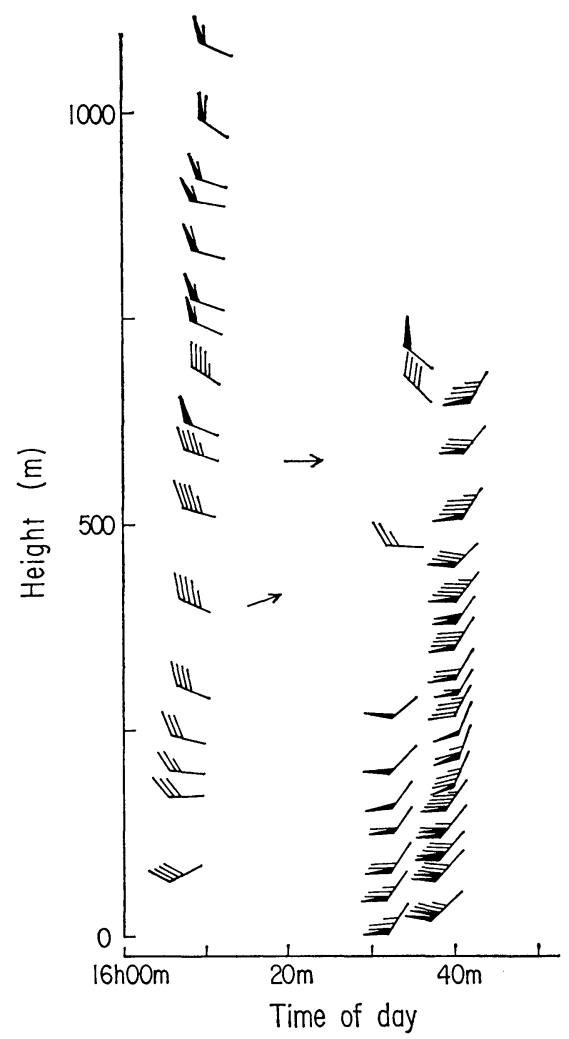

Fig. 6 Vertical structure of wind in front of squall. Pennant: $5 \mathrm{~m} / \mathrm{s}$. Barb: $1 \mathrm{~m} / \mathrm{s}$. Halfbarb: $0.5 \mathrm{~m} / \mathrm{s}$. Arrow: downwind direction from tethered-balloon.

Table 3 Cross-isobar angle and ratio of actual to geostrophic wind speed

\begin{tabular}{lrrrrc}
\hline \multicolumn{1}{c}{\begin{tabular}{c} 
Date \\
\multicolumn{1}{c}{ Time (JST) }
\end{tabular}} & May 20 & May 20 & May 21 & May 21 \\
& 09 & 15 & 09 & \multicolumn{1}{c}{13} \\
\hline Actual wind & direction (deg) & 338 & 332 & 316 & 301 \\
(100 m ht.) & speed (m/s) & 6.9 & 7.4 & 5.1 & 5.7 \\
Geostrophic wind & direction (deg) & 31 & $28^{*}$ & 351 & $351^{* *}$ \\
(1000 mb) & speed (m/s) & 18.7 & $27.0^{*}$ & 24.8 & $24.1^{* *}$ \\
Gross-isobar angle (deg) & 53 & 56 & 35 & 50 \\
Ratio of actual to geostrophic wind speed & 0.37 & 0.27 & 0.21 & 0.23 \\
\hline Actual wind & direction (deg) & 319 & 313 & 271 & 270 \\
(1400 m ht.) & speed (m/s) & 7.6 & 8.7 & 5.8 & 7.7 \\
Geostrophic wind & direction (deg) & 8 & $19^{*}$ & 12 & $12^{* *}$ \\
(850 mb) & speed (m/s) & 17.5 & $31.5^{*}$ & 33.8 & $33.8^{* *}$ \\
Cross-isobar angle (deg) & 49 & 66 & 101 & 102 \\
Ratio of actual to geostrophic wind speed & 0.43 & 0.28 & 0.17 & 0.23 \\
\hline
\end{tabular}

* Interpolations from those at 09 and 21 JST, May 20

** same as those at 09 JST, May 21 
three ascents, the latter two are the results from the pilot-balloon ascents and the former is that from the LTS ascent. Here, wind speed and direction are deduced from smoothed horizontal coordinates of the balloon, depth of the averaged layer left irregular owing to the present observing method. The second ascent of the pilotballoon shows that almost uniform winds occur in the lowest several hundred meters layer of the atmosphere. Wind speed is considerably strong, exceeds $10 \mathrm{~m} / \mathrm{s}$ in the lowest observing level and direction is about 215 degrees. On the other hand, the first ascent of the pilot-balloon shows a layered structure of wind. Below 200 meters height above the sea surface, wind field is similar to that in the second ascent, but wind speed evidently decreases with increase in height. At higher level, wind begins to veer with height and its speed is weaker than that in the lower level. For both ascents, pilot-balloons entered into clouds at about 3.5 minutes after release, that is, at about 700 meters height above the sea surface. It is likely that significant vertical motion of air takes place in the vicinity of the squall cell and affects the flight of the pilotballoon in such a way that the real ascent rate is considerably different from the nominal one. The height of the cloud base deduced from the nominal ascent rate is, however, in good agreement with that determined from cable length of the tethered-balloon which was flown for an observation made between LTS and pilot-balloon ascents. * Wind field obtained from a LTS observation carried out before pilot-balloon ascents is similar to that obtained in the higher level of the first ascent. Wind directions obtained from the tethered-balloon observation* are also shown in the Figure, which show westerly wind, too. There is no quantitative observation about the scale, advancing speed and direction of the squall cell. It can, however, be concluded from a rough sketch of the tethered-balloon observation showing the clouds around the R.V. Hakuho Maru (not shown)* and records of the ship heading that the advancing direction of the cell is almost parallel to the wind direction observed in the second ascent. Although the advancing speed of the cell can not be definitely determined, the Figure is considered to provide a sample picture of downdraft in front of the squall. The depth of "a density current" by the downdraft is about

\footnotetext{
* By courtesy of Mr. M. Gamo of National Research Institute for Pollution and Resources.
}

two hundred meters above the sea surface. This squall significantly modified the thermodynamical structure of the boundary layer on its passage (Monji et al., 1981).

\section{Concluding remarks}

The pilot-balloon observation on board which has not been so much reported was done successfully in the MONEX cruise of the R.V. Hakuho Maru in May, 1979. A wind-finding procedure involving calculation of balloon coordinates with correction for ship sway and smoothing of balloon trajectory by use of variational filtering technique provides reliable wind profiles. Nearly twenty profiles in the lowest 1500 meters layer of the atmosphere averaged over about an hour were obtained in seven days during the period of two weeks. Over the equatorial ocean, the well mixed layer is found in the lowest several hundred meters layer of the atmosphere from observation of temperature and humidity aloft. It is found that the wind field in the boundary layer also shows the characteristics of the mixed layer, that is, the layer of uniform wind speed and direction in the vertical. The depth of the layer corresponds with that of the mixed layer determined from the thermodynamical structure of the boundary layer. Such characteristics is, however, difficult to be found in the pilot-balloon observation made on small islands in the vicinity of the Equator in May, 1956. It is suggested that this discrepancy is due to whether the observation is made in the undisturbed trade wind situation or not.

Cross-isobar angles and ratios of actual to geostrophic wind speed are estimated for the last four pilot-balloon observations by use of atmospheric pressure measurements on research vessels and small islands in the tropical western Pacific. The angles amount to about 50 degrees and the ratios are about 0.3 at around 100 meters height above the sea surface, in good agreement with climatological value in the lower latitudes. Of course, the results are taken merely as a research material for further comprehensive studies.

Successive pilot-balloon observations were made just before the occurrence of squall. An evidence is obtained that the depth of "a density current" by the downdraft in front of the squall is about two hundred meters height above the sea surface.

Finally, the authors express their hearty thanks to Assistant Prof. N. Monji of Kyoto University 
and Mr. H. Yoshikado of National Research Institute for Pollution and Resources for their cooperation for the pilot-balloon observation on board of the R.V. Hakuho Maru and Mr. O. Tsukamoto of Kyoto University for his helpful assistance in data processing. They wish to express their sincere thanks to Prof. R. Yamamoto of Kyoto University for suggesting the analysis of the pilot-balloon data of Operation REDWING and giving constant encouragement to them. Thanks are also due to Prof. T. Asai, the Chief Scientist for the MONEX cruise, of the University of Tokyo, Captain I. Tadama and all the crew of the R.V. Hakuho Maru.

\section{References}

Aspliden C. I., R. S. Hipskind, J. B. Sabine, P. Valkenaar and R. L. DeSouza, 1978; Three-dimensional wind structure around convective elements over a tropical island, Tellus, 30, 252-259.

Augstein, E., 1972; Mass and heat budget estimations of the Atlantic SE trade wind flow at the Equator, "Meteor" Forsch.-Ergebnisse, B, 8, 31-41.

Augstein, E., H. Schmidt and F. Ostapoff, 1974; The vertical structure of the atmospheric planetary boundary layer in undisturbed trade winds over the Atlantic Ocean, Boundary-Layer Meteor., 6, 129-150.

Axford, D. N., 1968; On the accuracy of wind measurement using an inertial platform in an aircraft, and an example of a measurement of the vertical mesostructure of the atmosphere, J. Appl. $\mathrm{Me}$ teor., 7, 645-666.

Barnes, G., G.D. Emmitt, B. Brümmer, M.A. LeMone and S. Nicholls, 1980; The structure of a fair weather boundary layer based on the results of several measurement strategies, Mon. Wea. Rev., 108, 349-364.

Brümmer, B., 1976; The kinematics, dynamics and kinetic energy budget of the trade wind flow over the Atlantic Ocean, "Meteor" Forsch.Ergebnisse, B, 11, 1-24.

Charnock, H., J.R.D. Francis and P.A. Sheppard, 1956; An investigation of wind structure in the trades: Anegada 1953; Phil. Trans. Roy. Soc. London, A, 249, 179-234.

Clarke, R.H. and G.D. Hess, 1975; On the relation between surface wind and pressure gradient, especially in lower latitudes, Boundary-Layer $\mathrm{Me}$ teor., 9, 325-339.

Düing, W. (ed.), 1980; GATE, 2 vols., Pergamon Press.

Estoque, M. A., 1971; The planetary boundary layer wind over Christmas Island, Mon. Wea. Rev., 99, 193-201.

Fitzjarrald, D.R. and M. Garstang, 1981; Vertical structure of the tropical boundary layer, Mon.
Wea. Rev., 109, 1512-1526.

Gordon, A.H., 1952; The relation between the mean vector surface wind and the mean vector pressure gradient over the ocean, Geofisica Pura e Applicata, 21, 49-51.

Hastenrath, S., 1972; Daily wind, pressure, and temperature variation up to $30 \mathrm{~km}$ over the tropical western Pacific, Quart. J. Roy. Meteor. Soc., 98, 48-59.

Holland, J.Z. and E.M. Rasmusson, 1973; Measurement of the atmospheric mass, energy, and momentum budgets over a 500-kilometer square of tropical ocean, Mon. Wea. Rev., 101, 44-55.

Kraus, E.B. and H.P. Hanson, 1974; Climatological aspects of the tropical convective boundary layer, Bounadry-Layer Meteor., 6, 219-233.

Krivelevich, L. M. and D. L. Laykhtman, 1975; A model of the equatorial boundary layer of the ocean, Izv. Acad. Sci. USSR., Atmos. Oceanic Phys., 11, 811-815

Mahrt, L.J., 1972; A numerical study of the influence of advective accelerations in an idealized, low-latitude, planetary boundary layer, J. Atmos. Sci., 29, 1477-1484.

Mizuma, M. and S. Iwamoto. 1980; Pilot-balloon observation, MONEX/EGGE Data Report, Edited by $\mathrm{T}$. Izawa.

Monji, N., H. Yoshikado and Y. Mitsuta, 1981; Structure of the tropical boundary layer, Bull. Disaster Prevention Res. Inst., Kyoto Univ., 24, B-1, 371-380, (in Japanese).

Nicholls, S. and M.A. LeMone, 1980; The fair weather boundary layer in GATE: The relationship of subcloud fluxes and structure to the distribution and enhancement of cumulus clouds, J. Atmos. Sci., 37, 2051-2067.

Ninomiya, K. and T. Akiyama, 1978; Objective analysis of heavy rainfalls based on radar and gauge measurements, J. Meteor. Soc. Japan, 56, 206210.

Ninomiya, K. and T. Akiyama, 1979; Objective analysis of rainfall distribution and displacement of heavy rainfall area based on radar and gauge measurements for surveillance of heavy rainfalls, Tenki, 26, 19-26, (in Japanese).

Prümm, D., 1976; Note on the diurnal variations of air pressure and wind in the Atlantic surface layer, "Meteor" Forsch.-Ergebnisse, B, 11, 94-101.

Pushistov, P.Yu., 1970; The planetary atmospheric boundary layer in the equatorial region, $I z v$. Acad. Sci. USSR., Atmos. Oceanic Phys., 6, 321-325.

Riehl, H., 1979; Climate and weather in the tropics, Academic Press, 11

Romanov, Yu.A. and N.A. Romanova, 1976; Some results of the surface wind and atmospheric pressure fields analysis near the Equator, Tellus, 28, 524-532. 
Sasaki, Y., 1958; An objective analysis based on the variational method, J. Meteor. Soc. Japan, 36, 77-88.

Sheppard, P.A. and M.H. Omar, 1952; The wind stress over the ocean from observation in the Trades, Quart. J. Roy. Meteor. Soc., 78, 583589.

Sinha, S. and V.V. Khade, 1980; Some characteristics of the PBL over the ocean during the indian summer monsoon, Boundary-Layer Meteor., 19, 235-247.

Wagner, K., 1971; Variational analysis using observational and low-pass filtering constraints, M.S. Thesis, The Univ. of Oklahoma.

Yoshikado, H. and N. Monji, 1980; Temperature and humidity profile by use of Lower Troposphere Radiosonde on Hakuho Maru, MONEX/ FGGE Data Report, Edited by T. Izawa.

\section{熱帯海洋上の境界層の風の構造}

\section{水 間 満 郎・岩 本 智之 \\ 京都大学原子炬実験所}

我国の MONEX 観測計画の一環として, 境界層の風のプロフィルの船上観測が西太平洋の赤道海域に特い て実施された。本研究のために船船上でのパイボール観測の新しいシステムが開発された。観測された境界層風 は，鉛直方向に一様な混合層的な様相を示す。一様な風の層の厚さは熱的に決められた混合層の厚さと同程度で ある。この結果は, 熱的な混合層の中で風速の鉛直シアーが認められている，熱帯貿易風中での一般的な知見と 異っているように思われる。境界層風と等王線のなす角度および実測風速と地衡風速の比について得られた 2,3 の結果は, 低緯度地域についての気候学的な值と良く一致する。スコールの前面に拈ける下降気流による吹き出 しの観測例が得られ，吹き出しの厚さは海面上 $200 \mathrm{~m}$ 程度とみられる。 